\title{
Empirical Assessment on the Impact of Leverage and Capital Adequacy on Performance of Non-Bank Financial Institutions in Bangladesh
}

\author{
By Liton Chandro Sarkar
}

\begin{abstract}
Non-Bank Financial Institutions (NBFIs) epitomize the most significant source of financing in our economy. NBFI is highly levered in nature. This study tries to empirically identify how capital adequacy and leverage impact NBFIs' performance in Bangladesh. A number of econometric models using panel data from 2009 to 2019 of 23 NBFIs of Bangladesh have been estimated to achieve the objective of this study. In this research, Return on Assets, Return on Equity and Tobin's $Q$ are used as a measure of NBFIs performance of Bangladesh. According to estimated result it has been found that capital adequacy has a positive effect on profitability of NBFI's in Bangladesh. However, the research has found conflicting results when impact of leverage on NBFI performance is measured. Taking the empirical findings into consideration, the management of the NBFIs should embrace policies that are likely to help the NBFIs to maintain enough capital.
\end{abstract}

Keywords: leverage, capital adequacy, NBFI performance, profitability, NBFI equity

\section{Introduction}

Most of the NBFIs in Bangladesh is a profit oriented monetary and financial transitional organization which usually accepts term deposits, offers loan and finance funds among businesses, NBFIs and individuals. A sound and healthy financial system is very crucial for any economy. If an NBFI fails, it would affect its retail and institutional clients which could trigger a negative multiplier effect on the economy. To maintain customers' trust, a proper regulatory framework is required in this industry. NBFI capital which functions as buffer against losses is one of the most important parts of the regulatory framework. According to Sharp (1964), the amount that a NBFI holds apart from assets and deposits is called the NBFI capital. It is evident from the definition that higher level of capital makes a NBFI safer for its depositors. Adequate capital is the level of capital that a NBFI should keep ensuring the prudent business operations (Nwankwo 1991).

High leverage (higher level of debt) is one of the major characteristics of NBFI as the NBFI is a loan and deposit driven organization. Improper blend of debt and equity in a firm may lead to financially painful situation like shrinking profit. Finding the perfect combination of debt and equity is a challenging task for managers as the optimum use of leverage differs from industry to industry. Miller and Modigliani (1958), in one of the earlier studies presented "The Irrelevance

"Deputy Director, Bangladesh University of Professionals (BUP), Bangladesh. 
Theory of Capital Structure" argued that a business's basic earning power entirely determines its value and decision regarding capital structure does not influence a business enterprise's worth in an effortlessly competitive market condition.

There were numerous studies and researches conducted in the banking industry to explore the association and relationship among leverage, capital adequacy and a firms' performance. However, those researches have showed a mixed result. Gilbert and Wheelock (2007) argue that capital adequacy requirement improves the safety and quality of the banks and has positive impact on profitability. However, alternative school of thought is also present in the literature. Cavallo and Majnoni (2001) showed that the high capital requirements lead to contraction of NBFI credit which eventually lowers the profit. In a study conducted in the context of European countries, Gleason et al. (2000) revealed that a firms' leverage has a considerable negative impact on financial firms' performance. On the other hand, James and Hadlock (2002) found that companies' performance and leverage are positively related. James and Hadlock (2002) also stated that use of higher level of debts leads to higher profitability. Likewise, Holz (2002) also suggest similar relationship. According to Smith and Watts (1992), growth potential of a business and corporate leverage has a negative relationship. In a study on bank, Schepens (2016) emphasizing on the uneven tax treatment on debt and equity of banks. He claimed that a more alike treatment of banks debt and equity leads to upsurge in the level of common equity which eventually increases bank capital ratios.

In Bangladesh, NBFS have been regulated and given license under the Financial Act-1993 and controlled by Bangladesh Bank. Under this act there also a regulation which name is the "Financial Institution Regulation-1994". According to the Financial Institution Regulation-1994, the minimum paid-up capital for NBFIs in Bangladesh is BDT. 1.0 (one) billion. Compare with banks in Bangladesh, NBFIs commercial operating line is narrow. NBFIs in Bangladesh are permitted to take periodical deposit from 2013. The first NBFI was established in 1981. According to Bangladesh Bank data, at present 34 NBFIs are operated in Bangladesh. Among them 19 NBFIs are private owned, 12 NBFIs are joint venture and rest of 3 are government-owned. Total branches of NBFI are 276. While out of 34 NBFIs only 23 NBFIs are listed Bangladesh Stock market. The structure and branches of NBFIs in Bangladesh are shown in Table 1.

Table 1. Structure and Branches of NBFIs, Bangladesh (As on 30 June, 2020)

\begin{tabular}{|l|c|c|c|c|c|c|c|c|}
\hline \multirow{2}{*}{ Structure of NBFIs } & \multicolumn{10}{|c|}{ Year } \\
\cline { 2 - 12 } & 2013 & 2014 & 2015 & 2016 & 2017 & 2018 & 2019 & 2020 \\
\hline Government-owned & 3 & 3 & 3 & 3 & 3 & 3 & 3 & 3 \\
\hline Joint Venture & 10 & 10 & 10 & 11 & 12 & 12 & 12 & 12 \\
\hline Private & 18 & 18 & 18 & 19 & 19 & 19 & 19 & 19 \\
\hline $\begin{array}{l}\text { Total NBFIs in } \\
\text { Bangladesh }\end{array}$ & 31 & 31 & 31 & 33 & 34 & 34 & 34 & 34 \\
\hline \multicolumn{10}{|c|}{} & 2013 & 2014 & 2015 & 2016 & 2017 & 2018 & 2019 & 2020 \\
\hline No of Branches of NBFIs & 175 & 195 & 210 & 224 & 254 & 262 & 273 & 276 \\
\hline Total Branches &
\end{tabular}

Source: Department of Financial Institutions and Markets, Bangladesh Bank. 
The trends in assets, liabilities and deposits of NBFIs are shown in Table 2.

Table 2. Trends in Assets, Liabilities and Deposits of NBFIs, Bangladesh (in billion BDT) (As on 30 June, 2020)

\begin{tabular}{|l|c|c|c|c|c|c|c|c|}
\hline Particulars & 2013 & 2014 & 2015 & 2016 & 2017 & 2018 & 2019 & 2020 \\
\hline Total Assets & 436.3 & 520.1 & 611.0 & 713.9 & 841.1 & 870.3 & 870.3 & 874.3 \\
\hline Total Liabilities & 350.4 & 424.2 & 509.0 & 606.4 & 726.0 & 762.1 & 751.8 & 762.2 \\
\hline $\begin{array}{l}\text { Liabilities- Assets } \\
\text { Ratio }\end{array}$ & 80.3 & 81.6 & 83.3 & 84.9 & 86.3 & 87.6 & 82.2 & 87.1 \\
\hline Total Deposit & 198.3 & 238.5 & 318.1 & 382.4 & 468.0 & 480.1 & 458.1 & 459.4 \\
\hline $\begin{array}{l}\text { Deposit as \% of } \\
\text { Total Liabilities }\end{array}$ & 56.6 & 56.2 & 62.5 & 63.1 & 64.5 & 66.1 & 60.9 & 60.3 \\
\hline
\end{tabular}

Source: Department of Financial Institutions and Markets, Bangladesh Bank.

To the researchers' best knowledge there is a lack of academic researches related to determination of the influence of leverage and capital adequacy on NBFIs' performance in Bangladesh. Safiuddin et al. (2015) attempted to find capital structure's impact on the Bangladeshi firms using descriptive statistics. Safiuddin et al. (2015) examined the data of 10 firms for a five-year period (20082012) and found that leverage has negative effect on the organization's performance. Though, they did not use any econometric model to explain this relationship. The present study tries to fill this gap through econometric analysis involving variables linked to the NBFIs' financial performance, leverage and capital adequacy.

\section{Literature Review}

Numerous research and studies have been conducted on the profitability of the financial institutions. Most of most these researches had been conducted on bank. As decision regarding capital and debt is one of the major financial decisions for any firm, it has a strong presence in the financial academic literature. Miller and Modigliani (1958) suggest that optimal capital structure is nonexistent. In a fully effective capital market situation, there is no connection between companies' values and its capital structure. From then on, besides emphasizing on capital structure solely, some economists also paid attention to explore the way firm's capital structure influences performance.

This research tries to examine the impact of leverage and capital adequacy on the NBFIs' performance or profitability. In line with the objective of the study most relevant literatures on this issue will be discussed from now on.

As an extension to MM theory Myers (1984) came up with static trade-off theory which accounts for the cost of bankruptcy and agency costs of leverage into attention. It suggested that tax could be avoided through debt financing but at the expense of risk increment. If the benefit from tax avoidance surpasses the cost 
associated with increased risk, a firm should consider adding leverage to its capital structure. Agency theory explains the relationship between firm's shareholders (principal) and firm's executives (agent). Agent is hired by the principal to run business. The concerns for this theory are the goal conflict between the principal and agent, and different risk tolerance level for the principal and agent. Signaling theory takes internal factors into account and suggests that asymmetry of information exists among investors and internal managers. Investors can judge value of this firm from the signal received from managers' decision on capital structure.

Examining the asset- liability ratio Ross (1977) suggested positive correlation between asset-liability ratio and company's value. Afterwards, Myers (1984) anticipated financial pecking order for an organization which start with firm's retained earnings, followed by loan financing, then issuance of equity and lastly comes to play in order to lessen the problem of uneven data and information between firms' investors and authorities.

The impact of capital on NBFI profitability is quite uncertain. In general, interest payments are reduced due to higher level of capital and that lowers the profitability by decreasing the tax shield coming from interest deductibility. But Berger (1995) argues that higher capital lowers the expected bankruptcy cost which positively impacts the profitability. On a study on U.S. commercial banks over the period from 1983-1989, he showed capital positively granger-causes the profitability. Correspondingly, from a study on a sample of NBFIs from Asian countries, Chien-Chiang and Hsieh (2013) found that capital ratios and NBFI profitability are positively correlated. There are also some other studies which found conflicting results. For instance, investigating a taster of banks from eight European countries, Goddard et al. (2013) stated a negative connection between capital and profitability ratios. Similarly, Altunbas et al. (2007) found that wellcapitalized NBFIs and banks in Europe are inefficient which causes lower profitability.

Unlike capital adequacy, Leverage showed positive impact on financial firms' profitability in the previous studies. Lawal (2014) argued that leverage plays major role in amplifying the value of Nigerian NBFIs and suggested that leverage usage would be promoted to upsurge the firm's value by managers, stockholders and regulators. Abubakar (2015) examined the relation between leverage and success of the NBFIs using a selective sample of 11 out of the 23 commercial NBFIs operating in Nigeria and found a positive correlation among debt to return on equity and equity ratio. Exploring an unbalanced panel data over the period 20052011, Beltratti and Paladino (2015) tried to find how leverage is related to income for international banks. They have established an econometric model considering both country specific variables and bank specific. They concluded and showed a positive correlation between the capital ratio and residual income for the global banking sector.

In the context of Iran, Ebrat et al. (2013) found the evidence of both positive and negative co-relationship between performance off firm and capital. They examined evidence from 85 Iranian companies from Tehran Stock Exchange. Yadav and Salim (2012) studied the performance of 237 Malaysian businesses 
organization and found a varied co-relationship between firm performance and capital structure. Leverage negatively affects the performance of firms where performance is measured through earning per share (EPS), ROE and ROA. But when growth is taken into consideration leverage seemingly has a positive effect on it. Zeitun and Tian (2007) showed a significant impact of a capital structure choice on the firms' performance. According to Manawaduge et al. (2011), use of more short-term in comparison to long-term debt to finance the operations is common for majority of the Sri Lankan companies.

Majority of the literature shows that capital adequacy and leverage have noteworthy and significant influence on the firms' performance. The scenario of Bangladeshi NBFIs is yet to be revealed.

\section{Objectives of the Research}

The board objective of this research is to evaluate and analyze the relationship among leverage, capital adequacy and firms' performance in the context of Bangladeshi NBFIs. To accomplish this principal objective, following specific objectives have been covered:

I. To quantify and identify the influence of leverage and capital adequacy on the NBFIs' performance in Bangladesh.

II. To provide some recommendations and policy guidelines based on the empirical results.

\section{Variables Construction}

Following variables identified for this research:

\section{NBFIs' Performance (Dependent Variable)}

According to Chakravarthy (1986), firms' financial performance is related to its purpose and persistence of maximizing profit for investors and shareholders while the firm's operational performance relates to expansions and growth resulting from sales and market value (Sandberg and Hofer 1987). Tobin's Q, ROA and ROE are used as proxy of financial performance in this research. The dependent variables of this study are distinct as follows:

$$
\begin{array}{r}
\text { Tobin's } Q=\frac{(\text { Market value of equity }+ \text { Book value of debt })}{\text { Book value of assets }} \\
R O A=\frac{\text { Profit after tax }}{\text { Total assets }} \\
\text { ROE }=\frac{\text { Profit after tax }}{\text { Total equity }}
\end{array}
$$




\section{Leverage and Capital Adequacy (Independent Variable)}

The most used indicator of NBFIs' capital adequacy is CAR (Capital Adequacy Ratio). But due to unavailability of the related data, total equity to total asset (CAP) ratio is used as substitution for capital adequacy in this study (Zheng et al. 2017). To get insight into the market perception, MBVR or the ratio of market value of the equity of the NBFI to book value of the same is also incorporated in the model. Total debt to total equity (TDTE) ratio has been used for leverage estimation. NBFI size calculated as logarithm of total asset (LogTA) is another independent variable in this model. As size is amalgamation of debt and equity, it is considered as a component of both capital adequacy and leverage.

In line with the previous researches mentioned above the researchers form expectations on the behaviour of independent variables on firm performance. Measures with expected impact of all the variables (dependent and independent) used here in this study are shown in the Table 3.

Table 3. Variables, Notations, Measures, Expected Impacts on the Performance of NBFIs and Sources of Data

Dependent Variables

\begin{tabular}{|c|c|c|c|c|}
\hline Variables & Notations & Measures & $\begin{array}{l}\text { Expected } \\
\text { Impact }\end{array}$ & $\begin{array}{l}\text { Sources } \\
\text { of Data }\end{array}$ \\
\hline Tobin's $Q$ & TQ & $\frac{(\text { Market value of equity }+ \text { Book value of debt })}{\text { Book value of assets }}$ & & $\begin{array}{c}\text { Annual } \\
\text { reports } \\
\text { and } \\
\text { DSE } \\
\text { website }\end{array}$ \\
\hline $\begin{array}{l}\text { Return on } \\
\text { Assets }\end{array}$ & ROA & $\frac{\text { Profit after tax }}{\text { Total assets }}$ & & $\begin{array}{l}\text { Annual } \\
\text { reports }\end{array}$ \\
\hline $\begin{array}{l}\text { Return on } \\
\text { Equity }\end{array}$ & ROE & $\frac{\text { Profit after tax }}{\text { Total equity }}$ & & $\begin{array}{l}\text { Annual } \\
\text { reports }\end{array}$ \\
\hline
\end{tabular}

Independent Variables

\begin{tabular}{|l|c|c|c|c|}
\hline Variables & Notations & Measures & $\begin{array}{c}\text { Expected } \\
\text { Impact }\end{array}$ & Sources of Data \\
\hline $\begin{array}{l}\text { Total Debt to Total } \\
\text { Equity }\end{array}$ & TDTE & $\frac{\text { Total debt }}{\text { Total } \text { equity }}$ & + & Annual Reports \\
\hline $\begin{array}{l}\text { Total Equity to } \\
\text { Total Assets }\end{array}$ & CAP & $\frac{\text { Total } \text { equity }}{\text { Total assets }}$ & $+/-$ & Annual Reports \\
\hline Size & LogTA & Log (Total assets) & $+/-$ & Annual reports \\
\hline $\begin{array}{l}\text { Market Value of } \\
\text { Equity to Book } \\
\begin{array}{l}\text { Value of Equity } \\
\text { Ratio }\end{array}\end{array}$ & MBVR & $\frac{\text { Market Value of Equity }}{\text { Book Value of Equity }}$ & $+/-$ & $\begin{array}{c}\text { Annual Reports } \\
\text { and DSE website }\end{array}$ \\
\hline
\end{tabular}

\section{Research Methodology}

With regard to research methodology, this research has been examined and analyzed on pragmatic outcomes from literature and applied those models on 
NBFIs in Bangladesh. The research tailed a quantitative approach. In this research, generally used secondary data collected from selected NBFIs' annual report for the development of initial model to analyze and scrutinize the impact of leverage and capital adequacy on the NBFIs' performance of Bangladesh. However, researchers have consulted with academics and NBFI professionals to derive recommendations. The researchers have selected the data of all 23 NBFIs enlisted in Dhaka Stock Exchange (DSE). Due to the unavailability of the data, the NBFIs which are not listed in the stock market are not included in the study. These NBFIs are observed over the years 2009-2019 (10 years), allowing the researchers to form a panel data set. Descriptive statistics analysis, diagnosis statistics analysis and correlation matrix analysis were used to understand the panel data.

\section{Empirical Model}

The empirical diagnostic model of the research assumes that profit or firms performance of NBFIs " $\mathrm{i}$ " in the period " $\mathrm{t}$ " depends on the leverage level and level of capital adequacy of NBFIs " $i$ " in the period " $t$ " with others independent variables which are expected to influence the NBFIs performance.

This study initially uses a pooled ordinary regression model as Park (2011) suggests OLS (Ordinary Least Squares) generate most consistent and efficient parameter estimates where individual effect $\mu_{i}$ (cross-sectional or time specific effect) does not exist $\left(\mu_{\mathrm{i}}=0\right)$.

Rendering to this assumption this research will analyze and examine the impact of leverage and capital adequacy on NBFIs' performance using the following regression models:

$$
\begin{aligned}
& T Q_{i t}=\beta_{0}+\beta_{1} C A P_{i t}+\beta_{2} T D T E_{i t}+\beta_{3} \log T A_{i t}+\beta_{4} M B V R_{i t}+\varepsilon_{i t} \\
& R O E_{i t}=\beta_{0}+\beta_{1} C A P_{i t}+\beta_{2} T D T E_{i t}+\beta_{3} \operatorname{LogTA}_{i t}+\beta_{4} M B V R_{i t}+\varepsilon_{i t} \\
& R O A_{i t}=\beta_{0}+\beta_{1} C A P_{i t}+\beta_{2} T D T E_{i t}+\beta_{3} \operatorname{LogTA}_{i t}+\beta_{4} M B V R_{i t}+\varepsilon_{i t}
\end{aligned}
$$

where, Tobin's $\mathrm{Q}$ or $T Q_{i t}$, Return on equity or $R O E_{i t}$ and Return on asset or $R O A_{i t}$ are financial performance indicators for NBFI $i$ in year $t$ CAP $_{\text {it }}$ (Total equity to Total assets ratio), TDTE $\mathrm{it}_{\mathrm{it}}$ (Total debt to Total equity ratio), $\log \mathrm{TA}_{\mathrm{it}}$ (size of the NBFIs) and $\mathrm{MBVR}_{\text {it }}$ (market value of equity to book value of equity ratio) are explanatory variables for the NBFI $i$ in year $t$ i. And $\beta_{0}-\beta_{4}$ are regression coefficients and $\varepsilon_{\text {it }}$ is the error term.

STATA statistical software has been used to conduct necessary statistical analysis starting from descriptive statistics to the development of the final model after cleaning the data for errors.

Pooled OLS does not provide the best result in the presence of heteroscedasticity and autocorrelation. Homoscedasticity, i.e., no heteroscedasticity suggests that each disturbance terms in model have the same variance and no autocorrelation means that disturbance terms are not correlated with each other (Greene 2012). If the individual effect $\mu_{\mathrm{i}}$ exists $\left(\mu_{i} \neq o \mu_{i} \neq \sigma\right)$ ) in the longitudinal data assumptions of having homoscedasticity and no auto correlation may be 
violated due to the heterogeneity (individual specific characteristics). This problem can be dealt in panel data model. This panel regression enables to control for the unobservable effects subject to entity. Fixed effect model assumes constant individual-specific error over time whereas random effect model assumes it random. Based on the nature of those issues either random effect or fixed effect model may be used.

\section{Fixed Effect and Random Effect Model}

The equation of "Fixed Effect Model" considering all the dependent variables of this study as PROFIT is:

$$
\operatorname{PROFIT~}_{i t}=\left(\beta_{0}+\mu_{i}\right)+\beta_{1} C_{A P}+\beta_{2} T_{i t} E_{i t}+\beta_{3} \operatorname{LogTA}_{i t}+\beta_{4} M B V R_{i t}+v_{i t}
$$

where, $\mu_{i}$ indicates random or fixed effect to NBFI or period of time that is excluded from the regression. It can be associated with other regressors as an individual effect is time invariant and treated as a part of the intercept. $v_{i t}$ represents independent and identically distributed error. Although, "Random Effect Model" is used to analyze the differences in error variance components across period of time or individual. Here, disparity across individuals (NBFIs) is supposed to be random and not correlated with the independent variables. The equation of random effect model is:

$$
\text { PROFIT }_{i t}=\beta_{0}+\beta_{1} \text { CAP }_{i t}+\beta_{2} \text { TDTE }_{i t}+\beta_{3} \operatorname{LogTA}_{i t}+\beta_{4} \text { MBVR }_{i t}+\left(\mu_{i}+v_{i t}\right)
$$

It has been presumed that, in a random effect model, individual effect (heterogeneity) and any predictor variables are not correlated. Based on this supposition, the model estimates error variance subject to times or groups (Park 2011).

\section{Diagnostic Tests for Model Selection}

Several diagnostic tests have been used to validate the estimated regression model in this research. Those are:

Test for Serial Autocorrelation

Drukker (2003) recommends that Wooldridge test can have better estimate in a practically sized sample. Wooldridge (2002) emanates with a modest test that is known as "Wooldridge test" to perceive serial correlation in the individual error term in a panel data framework.

\section{Test for Heteroscedasticity}

Heteroscedasticity means a condition where the variance of the regress and differs across the dataset. Heteroscedasticity creates problems in analysis as most 
approaches in regression analysis assume equal variance. Modified Wald test is used to identify groupwise heteroscedasticity in fixed effect model. Greene (2012, p. 324) shows the estimate for the Modified Wald test Statistic as follows:

$w^{n}=\sum_{i=1}^{n} \frac{\left(\hat{\sigma}_{i}^{2}-\hat{\sigma}^{2}\right)}{f_{i i}}$

Here, $\hat{\sigma}^{2} \hat{\sigma}^{2}$ is the disturbance variance estimator of the regression and $f_{i i} f_{i i}$ is estimate of $\operatorname{Var}\left[\hat{\sigma}_{i}^{2} \hat{\sigma}_{i}^{2}\right]$. The resulting test statistic is Chi-squared.

Test for Cross-Sectional Dependence

Cross-sectional dependence across errors may arise if there is existence of mutual shocks and overlooked components which eventually become chunk of the error term and error terms becomes correlated across cross- sections. This results in contemporaneous correlation which can be identified using Pesaran CD test suggested by Pesaran (2004).

\section{Hausman Specification Test}

Hausman (1978) proposes a specification test in econometrics that can be applied to hypothesis testing problems with two different estimators. To select between "Fixed Effect Model" and "Random Effect Model" Human Specification test has been applied in this research.

\section{Results and Discussion}

Same cross-sectional component has been observed over period of time in panel-data that ensures both time and space dimensions in dataset (Greene 2012). Due to this unique feature panel data can estimate better than only time series or cross-section data. With the support of STATA statistical software, regression analysis has been done to go in depth of the influence of capital structure on the selected Bangladeshi NBFIs performance.

Descriptive Analysis

The output of the descriptive statistics analysis of all the variables of the research is: 
Table 4. Summary of Descriptive Statistics

\begin{tabular}{|l|c|c|c|c|c|c|c|}
\hline Variable & ROE & ROA & TQ & CAP & TDTE & LogTA & MBVR \\
\hline Obs. & 291 & 291 & 283 & 291 & 291 & 291 & 282 \\
\hline Mean & 16.32 & 1.13 & 1.17 & 0.05 & 10.78 & 10.88 & 2.86 \\
\hline Std. Dev. & 19.25 & 2.25 & 0.46 & 0.08 & 28.58 & 0.32 & 6.56 \\
\hline Min & $(193.16)$ & $(22.93)$ & 0.46 & $(0.67)$ & $(414.66)$ & 10.14 & $(37.64)$ \\
\hline Max & 184.35 & 13.51 & 5.77 & 0.14 & 230.97 & 11.80 & 63.36 \\
\hline Variance & 370.82 & 5.08 & 0.21 & 0.001 & 817.44 & 0.10 & 43.10 \\
\hline Skewness & $(2.89)$ & $(4.56)$ & 5.31 & $(5.36)$ & $(9.77)$ & $(0.14)$ & 4.14 \\
\hline Kurtosis & 73.30 & 56.10 & 41.92 & 34.36 & 181.22 & 2.53 & 42.23 \\
\hline
\end{tabular}

Table 4 estimates the "Standard deviation", "Mean", "Minimum and Maximum" values of the variables, "Variance", "Skewness" and "Kurtosis" values. Thus, here the researcher provides a broad-spectrum summary of the features of the data. It can be noted that mean of all the variables (dependent and independent) is positive. However, the mean of ROA and ROE are 1.13 and 16.32 correspondingly which indicates moderate performance of the NBFIs during 2009-2019. The Tobin's Q mean value is 1.17. As Tobin's Q mean value is greater than one, it can be deduced that the market value of the NBFIs is more than their book values. This indicates that the profits made are greater than the expense of using assets of the selected NBFIs of interest and also suggests that additional investment is needed to be made by the selected NBFIs. In contrast, the mean of the CAP and TDTE are 0.05 and 10.78 respectively indicating a trifling amount of equity compared to debt of the NBFIs. MBVR is 2.86 , market value of equity being almost triple of book value of equity of the DSE enlisted NBFIs. The skewness shows that majority of the data are not symmetrical. Only LogTA is quite symmetrical. All the Kurtosis values are positive, and most of the values are much higher than zero meaning that the data do not follow normal distribution.

\section{Correlation Matrix Analysis}

Table 5. Summary of Combined Pair-Wise Correlation Matrix

\begin{tabular}{|l|c|c|c|c|c|c|c|}
\hline & TQ & ROE & ROA & CAP & TDTE & LogTA & MBVR \\
\hline TQ & 1 & & & & & & \\
\hline ROE & - & 1 & & & & & \\
\hline ROA & - & - & 1 & & & & \\
\hline CAP & 0.3143 & -0.0481 & -0.3727 & 1 & & & \\
\hline TDTE & -0.016 & 0.6246 & 0.0444 & 0.0988 & 1 & & \\
\hline LogTA & -0.1810 & -0.1633 & 0.1845 & 0.3921 & -0.0028 & 1 & \\
\hline MBVR & 0.6676 & 0.3666 & 0.0898 & 0.1003 & 0.5821 & -0.052 & 1 \\
\hline
\end{tabular}

The matrix in Table 5 shows the combined pair-wise correlation calculations. Tobin's Q is positively correlated to CAP and MBVR while it is negatively 
correlated to TDTE and LogTA of the NBFIs. ROE is positively correlated TDTE and MBVR, whereas it is negatively correlated to CAP and LogTA. ROA is positively correlated to all the independent variables except CAP. Most of the relationships are quite weak except for the correlation between ROE and TDTE, and Tobin's Q and MBVR.

\section{Diagnostic Analysis}

In Table 4, the outcomes of the "Modified Wald" test for groupwise heteroscedasticity in "Fixed Effect Regression Model" tests for three models are mentioned. The researcher has gone for the test of heteroscedasticity and the result is the presence of heteroskedasticity. Table 6 shows that heteroskedasticity is present in all the three models, meaning that the variances of the error terms vary from observation to observation.

Wooldridge test for auto-correlation in panel data for the three models was done in STATA statistics software and the results are shown in Table 6 representing that all the models contain autocorrelation. Therefore, there is correlation between the members of the series of observations ordered in time.

Table 6. Heteroskedasticity, Autocorrelation and Cross-Sectional Dependence Test Results

\begin{tabular}{|c|c|c|c|}
\hline \multicolumn{4}{|c|}{ Tests } \\
\hline & Tobin's Q & ROE & ROA \\
\hline \multicolumn{4}{|c|}{ "Modified Wala" Test (For Groupwise Heteroskedasticity) } \\
\hline \multicolumn{4}{|c|}{$\mathrm{H}_{0}: \operatorname{sigma}(\mathrm{i})^{2}=\operatorname{sigma}^{2}$ for all $\mathrm{i}$} \\
\hline$\chi^{2}(30)$ & $1.5 \mathrm{e}+08$ & 11640.25 & 21723.69 \\
\hline Prob. $>\chi^{2}$ & 0.0000 & 0.0000 & 0.0000 \\
\hline \multicolumn{4}{|c|}{ "Wooldridge" Test (For Autocorrelation) } \\
\hline \multicolumn{4}{|c|}{$\mathrm{H}_{0}:$ No autocorrelation } \\
\hline $\mathrm{F}(1,29)$ & 9.063 & 28.727 & 21.291 \\
\hline Prob. > F & 0.0054 & 0.0000 & 0.0001 \\
\hline \multicolumn{4}{|c|}{ "Pesaran" Test (For Cross-sectional dependence) } \\
\hline \multicolumn{4}{|c|}{$\mathrm{H}_{0}:$ No Cross-Sectional dependence } \\
\hline $\begin{array}{l}\text { "Pesaran" Test } \\
\text { results }\end{array}$ & 6.642 & 31.286 & 20.837 \\
\hline Prob. & 0.00 & 0.00 & 0.00 \\
\hline
\end{tabular}

Table 6 also shows the outcomes of "Pesaran's" cross-sectional dependence test. The outcomes of the "Pesaran" test demonstration that there is cross-sectional dependence among the data of all the three models.

Here in Table 7, for all the three models, $\mathrm{H}_{0}$ : Difference in coefficients is not systematic (Random Effect) 
Table 7. Hausman Test for Tobin's Q, ROA and ROE Model

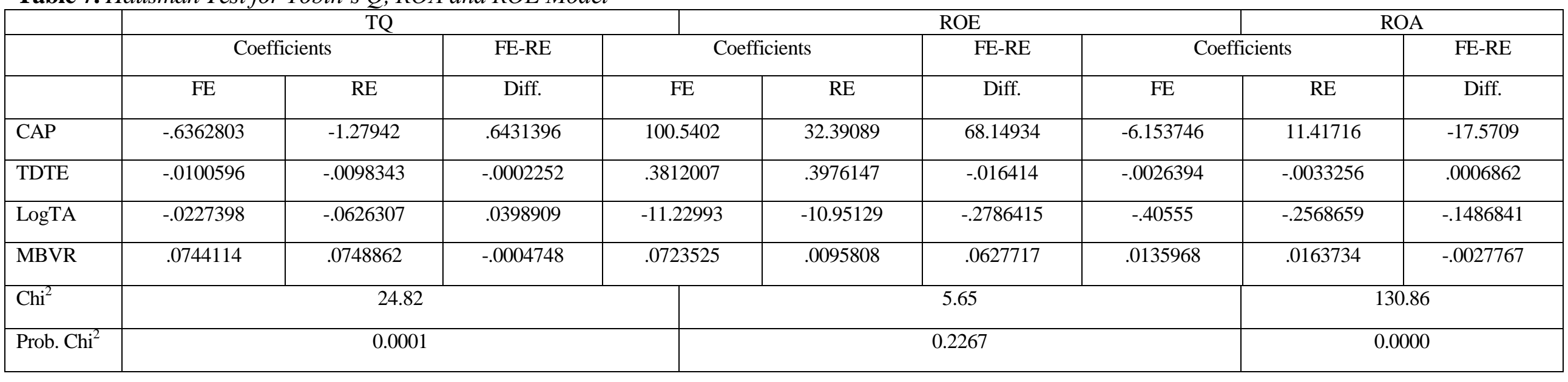


The null hypothesis has been rejected for Tobins'Q model and ROA model. This suggests presence of fixed effect. On the other hand, presence of random effect has been suggested for ROE model as we fail to reject the null hypothesis.

\section{Selection of Final Model}

Selection of model that provides best estimate is the major concern of panel data analysis. As there is indication of first order auto-correlation and heteroscedasticity in the dataset of this study, general pooled ordinary least square model may lead to biased estimate. To handle this issue random effect and fixed effect models are assessed. According to Hausman specification test, fixed effect has been found when Tobin's Q and ROA have been used as dependent variable. In the presence of cross-sectional dependence, Driscoll and Kraay (1998) standard errors for coefficient assessed by fixed effects (within) regression will provide the best estimate. On the other hand, due to presence of the random effect and crosssectional dependence, PCSE or Panel Corrected Standard Error method has been applied in the model where ROE is the dependent variable. Using STATA statistics software, the researchers found the result of this regression model which is presented in the Table 8 .

The final model for Tobin's Q in Table 6 displays that the independent variables TDTE and MBVR are significant at $1 \%$ significance level. Among them TDTE has negative relationship with Tobin's Q whereas the relationship between Tobin's Q and MBVR is positive. It indicates that the less the debt compared to equity, the more the profit. And when NBFIs have the equities' market value more compared to the book value of the same, the performance becomes better.

Table 8. Final Models for the Three Estimated Equations

\begin{tabular}{|l|c|c|c|}
\hline \multirow{2}{*}{ Variables } & \multicolumn{3}{|c|}{ Coefficient of Variables } \\
\cline { 2 - 4 } & Tobin's Q & ROE & ROA \\
\hline \multirow{2}{*}{ CAP } & -0.636 & $34.3019^{* * *}$ & -6.153 \\
& $(-1.45)$ & $(3.00)$ & $(-1.65)$ \\
\hline \multirow{2}{*}{ TDTE } & $-0.01006^{* * *}$ & $0.4001^{* * *}$ & -0.0026 \\
& $(-4.45)$ & $(14.44)$ & $-0.72)$ \\
\hline \multirow{2}{*}{ LogTA } & -0.0227 & $-14.6211^{* * *}$ & -0.4055 \\
& $(-0.75)$ & $(-2.34)$ & 0.0135 \\
\hline \multirow{2}{*}{ MBVR } & $0.0744^{* * *}$ & 0.0584 & $(0.78)$ \\
& $(5.04)$ & $(0.54)$ & 6.030 \\
\multirow{2}{*}{ Cons. } & $1.36037 * * *$ & 168.463 & $(1.37)$ \\
\hline Diagnostic statistic of the estimated models & $(4.06)$ & 0.0543 \\
\hline $\mathrm{R}^{2}$ & 0.7535 & 0.5241 & 0.3901 \\
\hline F/chi^2 & 21.55 & 384.97 & . \\
\hline
\end{tabular}

The final model for ROE shows that the independent variables CAP, TDTE and LogTA (NBFI size) are significant at $1 \%$ level. Among them, TDTE and CAP 
have a positive relationship with ROE whereas LogTA has negative relationship with ROE. This indicates that the effect of capital adequacy on the performance of NBFIs is positive. In this research, a negative relationship also found between TDTE with NBFIs performance in the model for Tobin's Q. But in this model for ROE found a positive relationship between them. The outcome of ROE model also suggests the smaller the NBFI's size, the better the NBFI's performance.

The final model for ROA shows that no variable is truly significant. Diagnostic statistic also indicates a poor explanatory power of this model whereas models for Tobins' Q and ROE show quite satisfactory explanatory power.

\section{Recommendations}

The regulatory authority and NBFI management may take the following issues into their consideration according to the findings of this study.

1. As capital adequacy positively impacts the financial performance of NBFI, NBFI management should think of strengthening capital base through maintaining sufficient capital to monitor the use of leverage in NBFI's asset.

2. As we cannot be sure about the effect of leverage NBFI profitability, the regulatory institutions of NBFIs along with the management of NBFIs, should adopt policies that are likely to monitor the use of debt instruments with more caution.

3. Empirical result displays that MBVR has significant positive relationship with NBFIs performance. Most of the Bangladeshi NBFIs in the study are vastly levered. Equity's market value is almost triple of its book value of the NBFIs of interest. It suggests that investors' trust reflects in the NBFI performance. Further studies can be done in this regard.

4. As size of the NBFI negatively affects the NBFI performance, the NBFIs which are big in terms of total asset should try to focus on profitability rather than on expanding the size.

5. According to the Business Standard Report (2020), because of the liquidity crisis, 06 (Six) NBFIs are now in a defenseless and vulnerable state after PLFS (Peoples Leasing and Finance Services) and BIFC (Bangladesh Industrial Finance, which are stimulating and bracing for liquidation. Therefore, related authority and stake holder should concentrate on increasing and updating the credit evaluation policy and procedure, loans, advances, leases, interest income and diversification of products for improving their profitability.

6. Government and stakeholder should attempt to uphold and maintain stable development and growth to increase public sureness and confidence in NBFIs of Bangladesh. 


\section{Conclusion}

The basis of this research is to empirically examine the effect of leverage and capital adequacy on NBFIs performance of Bangladesh. Taking into account that information and data were gathered from the yearly reports of 23 (Twenty-three) enrolled enlisted NBFIs of DSE for the period of last ten years from 2009 to 2019. It was found TDTE and MBVR significantly affect NBFI performance. The researchers have found CAP, TDTE and LogTA (NBFI size) as significant independent variable using ROE as dependent variable. However, there is no significant correlation among leverage, capital adequacy and performance of Bangladeshi NBFIs' when performance is measured by ROA. Evidence from empirical result suggests that capital adequacy has positive influence on the profitability of Bangladeshi NBFIs whereas size negatively affects the performance of NBFIs. Leverage has significant impact on NBFI profitability but the study is inconclusive to make comment on the direction of the significance as leverage shows both positive and negative relationship with NBFI performance. Thus, there is a mixed result regarding the influence of capital adequacy and leverage on NBFIs' performance which is reliable with the findings of existing literature.

There is scope for further study regarding the impact of leverage and capital adequacy on NBFIs' performance by considering some other ratios as proxy of capital adequacy and leverage. There has been a limitation in this study of not having access to data of capital adequacy ratio (CAR). Some of the commercial NBFIs have also been excluded from the study due to data unavailability. In spite of the limitation, the researchers have given their full effort to make the study a valuable one which might help the policy makers to bring effective decisions for the profitability and growth of the NBFIs of Bangladesh.

\section{References}

Abubakar A (2015) Relationship between financial leverage and financial performance of deposit money banks in Nigeria. International Journal of Economics, Commerce and Management 3(10): 759-778.

Altunbas Y, Santiago C, Edward PG, Philip M (2007) Examining the relationships between capital, risk and efficiency in European banking. European Financial Management 13(1): 49-70.

Bangladesh Bank Annual Report (2018-2019) Performance, regulations and supervision of NBFIs. Chapter 7. Bangladesh Bank.

Beltratti A, Paladino G (2015) Bank leverage and profitability: evidence from a sample of international banks. Review of Financial Economics 27(Nov): 46-57.

Berger AN (1995) The relationship between capital and earnings in banking. Journal of Money, Credit and Banking 27(2): 432-456.

Cavallo M, Majnoni G (2001) Do Banks provision for bad loans in good time? Empirical evidence and policy implications. Policy Research Working Paper, 2619. Washington, DC: World Bank.

Chakravarthy BS (1986) Measuring strategic performance. Strategic Management Journal 7(5): 437-458. 
Chien-Chiang L, Hsieh MF (2013) The impact of bank capital on profitability and risk in Asian banking. Journal of International Money and Finance 32(1): 51-81.

Driscoll JC, Kraay AC (1998) Consistent covariance matrix estimation with spatially dependent panel data. Review of Economics and Statistics 80(4): 549-560.

Drukker DM (2003) Testing for serial correlation in liner panel-data models. The Stata Journal 3(2): 168-177.

Ebrat R, Emadi F, Saadati R, Safari G (2013) The impact of capital structure on firm performance: evidence from Tehran stock exchange. Australian Journal of Basic and Applied Science 7(4): 1-8.

Gilbert RA, Wheelock DC (2007) Measuring commercial bank profitability: proceed with caution. Federal Reserve Bank St Louis Review 89(Nov): 515-532.

Gleason KC, Lynette KM, Ike M (2000) The interrelationship between culture, capital structure and performance: evidence from European retailers. Journal of Business Research 50(2): 185-191.

Goddard J, Hong L, Phil M, John OSW (2013) Do bank profits converge? European Financial Management 19(2): 345-365.

Greene WH (2012) Econometric analysis. $7^{\text {th }}$ Edition. Upper Saddle River, NJ: Prentice Hal.

Hausman JA (1978) Specification test in econometrics. Econometrica 46(6): 1251-1271.

Holz CA (2002) The impact of the liability-asset ratio on profitability in china's industrial state-owned enterprises. China Economic Review 13(1): 1-26.

James C, Hadlock C (2002) Do banks provide financial slack? Journal of Finance 57(3): $54-67$.

Lawal AI (2014) Capital structure and the value of the firm: evidence from the Nigeria banking industry. Journal of Accounting and Management 4(1): 31-41.

Manawaduge A, Zoysa A, Chowdhury K, Chandarakumara A (2011) Capital structure and firm performance in emerging economics: an empirical analysis of Sri Lankan firms. Corporate Ownership and Control 8(4): 253-263.

Miller MH, Modigliani F (1958) The cost of capital, corporate finance and the theory of investment. American Economic Review 48(3): 261-297.

Myers SC (1984) Capital structure puzzle. NBER Working Paper No W1393. National Bureau of Economic Research (NBER).

Nwankwo GO (1991) Bank management: principles and practice. Lagos: Maithouse Press Limited.

Park HM (2011) Practical guides to panel data modeling: a step-by-step analysis using stata. Tutorial Working Paper. Japan: Graduate School of International Relations, International University of Japan.

Pesaran MH (2004) General diagnostic tests for cross section dependence in panels. Cambridge Working Paper in Economics, No 0435. Cambridge: Faculty of Economics, University of Cambridge.

Ross SA (1977) The determination of financial structure: the incentive-signaling approach. The Bell Journal of Economics 8(1): 23-40.

Safiuddin M, Islam MM, Anisuzzaman M (2015) Impact of financial structure on firm's performance: a study on financial and non-financial sector in Bangladesh. European Journal of Business and Management 7(3): 30-38.

Sandberg WR, Hofer CW (1987) Improving new venture performance: the role of strategy, industry structure and the entrepreneur. Journal of Business Venturing 2(1): 5-28.

Schepens G (2016) Taxes and bank capital structure. Journal of Finance and Economics 120(3): 585-600.

Sharp WF (1964) Capital asset prices: a theory of market equilibrium under conditions of risk. The Journal of Finance 19(3): 425-442. 
Smith Jr. CW, Watts RL (1992) The investment opportunity set and corporate financing, dividend and compensation policies. Journal of Financial Economics 32(3): 263292.

The Business Standard Report (2020) Six more nonbank financial institutions in trouble. The Business Standard. Retrieved from: https://tbsnews.net/economy/banking/sixmore-non-bank-financial-institutions-trou ble. [Accessed 12 December 2020]

Wooldridge JM (2002) Econometric analysis of cross section and panel data. Retrieved from: http://public.econ.duke.edu/ vjh3/e262p_07S/reading s/Wooldridge_Panel_ Data_Chapters.pdf. [Accessed 15 June 2015]

Yadav R, Salim M (2012) Capital structure and firm performance: evidence from malaysian listed companies. Procedia-Social and Behavioral Sciences 65(Dec): 156166.

Zeitun R, Tian G (2007) Capital structure and corporate performance: evidence from Jordan. Australasian Accounting Business and Finance Journal 1(4): 40-61.

Zheng C, Rahman MM, Begum M, Ashraf BN (2017) Capital regulation, the cost of financial intermediation and bank profitability: evidence from Bangladesh. Journal of Risk and Financial Management 10(2): 9. 
